similar production potential. Lucerne hay (LH), maize silage (MS) and beet pulp silage (BP) were offered in ad libitum (AL) or restricted (R) quantities according to the following table :

\begin{tabular}{cc|c|c|c}
\hline \hline \multicolumn{1}{c|}{ Diets } & $\mathrm{A}$ & $\mathrm{B}$ & $\mathrm{C}$ \\
\hline \multirow{4}{*}{ Feed } & Lucerne hay $\ldots \ldots \ldots \ldots \ldots$ & $\mathrm{AL}$ & $\mathrm{R}$ & $\mathrm{R}$ \\
& Maize silage $\ldots \ldots \ldots \ldots$ & $\mathrm{R}$ & $\mathrm{AL}$ & - \\
Beet pulp silage $\ldots \ldots \ldots \ldots$ & - & - & $\mathrm{AL}$ \\
\hline
\end{tabular}

The organic matter digestibility (OMD) of these feeds was measured in vivo. In each experiment, the animals received the concentrate according to a previously determined programme. Results were recorded 1, 2, 4, 6 weeks after parturition.

The mean organic matter digestibility (OMD) were $71.2,76.0$ and $77.0 \%$ respectively for A, $B, C$. Improvement of the dietary OMD increased the levels of dry matter and energy intake ; consequently, the raw milk yield was about $300 \mathrm{~g} / \mathrm{d}$ higher with $\operatorname{diet} \mathrm{B}$ vs $\mathrm{A}$ and $\mathrm{C}$ vs $\mathrm{B}$ respectively, while the fat content was the same between A and B and only slightly smaller with diet C $(50.5 \%$ vs $51.7 \%)$. The calculated energy balance did not vary between diets A $(-0.86$ $\mathrm{Mcal} / \mathrm{d}), \mathrm{B}(-0.90)$ and $\mathrm{C}(-0.78)$ : however, the plasma glucose content was different significantly between diets $\mathrm{A}(0.540 \mathrm{~g} / \mathrm{l}), \mathrm{B}(0.593)$ and $\mathrm{C}(0.618)$ while the N.E.F.A. values showed a reverse hierarchy between diets A $(577.1 \mu \mathrm{eq} / 1)$, B (465.0) and C (385.9). These differences in energy intake and nutritive status influenced the milk fatty acid secretion : the $\mathrm{C} 4: 0$ to $\mathrm{C} 12: 0$ production was $22.4,28.8$ and $35.8 \mathrm{~g} / \mathrm{d}$ for diets $\mathrm{A}, \mathrm{B}, \mathrm{C}$ and the $\mathrm{C} 14: 0+$ $\mathrm{C} 16: 0$ level of production was $52.7,54.7$ and $60.6 \mathrm{~g} / \mathrm{d}$, and $\mathrm{C} 18: 0+\mathrm{C} 18: 1,51.6,51.7$ and $44.6 \mathrm{~g} / \mathrm{d}$ for diets $\mathrm{A}, \mathrm{B}$ and $\mathrm{C}$.

Such data emphasized the zootechnical and nutritional advantage of improving the OMD of goat diets through roughage choice at the onset of lactation.

Key words : Digestibility, goat, onset of lactation, energy balance.

\title{
Performance of Zaraibi and Damascus lactating does fed high and low energy rations
}

\author{
E.A. GIHAD, T.T. EL-GALLAD, S.M. ALLAM, T.M. EL-BEDAWY
}

Faculty of Agriculture, Cairo University, Giza (Egypt)

Fourty-six healthy lactating Zaraibi and 22 Damascus lactating does were used. The average body weight of these does was 30 and $40 \mathrm{~kg}$, respectively. This study started after gestation and lasted for 32 weeks. Does were housed and group-fed according to the NRC (1981) low activity standards. Milk production requirements were based on $1 \mathrm{~kg}$ daily $3.5 \%$ fat milk yield. Two energy levels, 100 and $125 \%$ on a starch equivalent basis were investigated using diets providing $40 \%$ of its net energy from roughages.

Available roughage were clover, hay and sweet sorghum which were fed along with a concentrate mixture to cover the rest of the energy needs. A proportional $25 \%$ increase of diet ingredients was applied to formulate the high energy rations.

The average daily milk yield in Zaraibi does during the whole experimental period was 0.691 and $0.715 \mathrm{~kg}$, respectively with low and high energy diets, and 0.743 and $0.960 \mathrm{~kg}$, respectively for Damascus does. Lactation ceased in does earlier than after 32 weeks. Therefore, the average lactation length was 208 and 182 days out of a total period of 224 days in Zaraibi does fed low and high energy diets while it was 170 and 203 days for Damascus does. According, total milk yield based on daily yield and lactation length showed that Zaraibi does produced 131.0 and $130.1 \mathrm{~kg}$ milk, respectively, with low and high energy diets, while Damascus does produced 126.6 and $194.9 \mathrm{~kg}$, respectively. 
Feeding high energy diets increased the daily milk yield of Damascus $(P<0.01)$ and Zaraibi does. A high energy intake only increased $(P<0.1)$ the lactation length in Damascus does and consequently increased $(\mathrm{P}<0.01)$ the total milk yield. The differences were however not significant when feeding Zaraibi does with a high energy level.

The overall results showed that the NRC (1981) energy standards could be satisfactorily practised with lactating Zaraibi does as a low productive breed. Increasing these standards by $25 \%$ could only be achieved in Damascus does which possess a high milk production potential.

A high energy intake did not affect the milk constituents except protein. It was only increased $(\mathrm{P}<.01)$ in Zaraibi does as shown by an increase $(\mathrm{P}<.05)$ in SNF. The milk composition of Damascus does did not show any significant differences by feeding high energy diets. The protein percent was 2.51 and 2.76 , respectively with low and high energy diets in Zaraibi does, while it was 3.04 and 2.93 respectively in Damascus does. The milk protein content of Damascus does was higher than that of Zaraibi does. A high milk protein content in milk has a technical importance for milk processing.

Key words : Goat, energy, milk production, Damascus, Zaraibi.

\title{
Comparative growth-performance of male goat kids and Yaez (ibex* goat) kids
}

\author{
D. RATTNER ${ }^{(1)}$, J. LANDAU ${ }^{(2)}$
}

(1) The Institute of Animal Research, Lahav, D.N. Negev 85335 (Israël). (2) Extention Service, Ministry of Agriculture, Rehovot 76262 (Israël).

The growth-performance of Yaez kids and Sinai goat kids was compared during two seasons of two years. The weight gain of the goat kids was better in the spring $[143 \mathrm{~g} / \mathrm{d}(\mathrm{n}=11$, s.d. $=9)$ vs. $114 \mathrm{~g} / \mathrm{d}(\mathrm{n}=9$, s.d. $=34), \mathrm{p}<0.05]$, whereas the Yaez kids grew better in the summer $[152 \mathrm{~g} / \mathrm{d}(\mathrm{n}=20$, s.d. $=40)$ vs. $98 \mathrm{~g} / \mathrm{d}(\mathrm{n}=8$, s.d. $=24), \mathrm{p}<0.05]$.

In a feeding experiment carried out in the summer, two pelleted concentrates of different energy concentration were fed to $\mathrm{Yaez}$ and goat kids : the metabolizable energy, crude protein and crude fiber concentrations of the high energy concentrate (HEC) and medium energy concentrate (MEC) were : $2.74 \mathrm{Mcal} / \mathrm{kg}, 16 \%, 4.5 \%$ and $2.56,16 \%, 6.1 \%$ respectively. The difference in energy was achieved by increasing the maize percentage and including $1.5 \%$ soapstock oil in the concentrate. The feed intake (experimental group average), average daily gain (individual) and feed efficiency in the Yaez kids fed HEC and MEC were $612 \mathrm{~g} / \mathrm{d}, 152 \mathrm{~g} / \mathrm{d}$ $(\mathrm{n}=11$, s.d. $=41), 4.0$ and $584 \mathrm{~g} / \mathrm{d}, 152 \mathrm{~g} / \mathrm{d}(\mathrm{n}=9$, s.d. $=38), 3.8$, and in the goat kids $682 \mathrm{~g} /$ $\mathrm{d}, 113 \mathrm{~g} / \mathrm{d}(\mathrm{n}=4$, s.d. $=33), 6.8$ and $654 \mathrm{~g} / \mathrm{d}, 92.5 \mathrm{~g} / \mathrm{d}(\mathrm{n}=4$, s.d. $=28), 7.1$, respectively. Feeding HEC did not improve the rate of growth in kids of the two breeds.

In another experiment in Yaez kids, three meals of concentrate per day vs. ad-libitum feeding were compared. The kids fed manualy were given MEC in a clean through at 6 a.m., 12 a.m. and 3 p.m., amount of feed was adjusted to be consumed in about $30^{\prime}$, at 10 a.m. about $250 \mathrm{~g} / \mathrm{kid}$ barley straw was fed. To the ad-lib group the MEC was presented in self-feeders and the same amount of barley straw was fed at the same time. The kids fed 3 meals daily consumed less feed $(584 \mathrm{~g} / \mathrm{d}$ vs. $802 \mathrm{~g} / \mathrm{d})$ and grew at a lower rate $[154 \mathrm{~g} / \mathrm{d}(\mathrm{n}=10$, s.d. $=35) \mathrm{vs.} 187 \mathrm{~g} / \mathrm{d}(\mathrm{n}=10$, s.d. $=30)$, difference not significant], but had a better feed conversion ratio (3.8 vs. 4.3).

The seasonal variation of growth-performance in goats and Yaez kids is tentatively explained by the analysis of their sexual maturation : since a slower sexual maturation rhythm is associated with the wild ibex genome, spring born Yaez kids display much less sexual activity in the summer than spring born goat kids and therefore grow better. No such behavioral difference is noted in the spring (out of the breeding season), since autumn and winter born kids of both genotype do not show excessive sexual activity at that time. It is suggested that the spring is the season when all kids grow at a rate which is the closest to their genetic potential.

Managerial conclusions can be drawn from these results : 1. Yaez kids may be slaughtered at an older age than goat kids in the summer, whereas the optimal slaughter age for both breeds may 